\title{
Professional Self-Concept and Critical Thinking of Pediatric Nurses in Turkey
}

\author{
Dilek Eryürük ${ }^{1}$ (D) , Zübeyde Korkmaz ${ }^{2}$ (D) , 0̈znur Başdaş ${ }^{3}$ (iD , Illknur Yıldız ${ }^{4}$ (D) , \\ Emine Erdem ${ }^{3}$ (D), Meral Bayat ${ }^{3}$ (D)
}

${ }^{1}$ Erciyes Üniversitesi, Sağlık Bilimleri Enstitüsü, Çocuk Sağlığı ve Hastalıkları Hemşireliği Doktora Programı Mezunu, Kayseri, Turkey

${ }^{2}$ Nuh Naci Yazgan Üniversitesi Sağlık Bilimleri Fakültesi, Kayseri, Turkey

${ }^{3}$ Erciyes Üniversitesi Sağlık Bilimleri Fakültesi, Kayseri, Turkey

${ }^{4}$ Cumhuriyet Universitesi Sağlık Bilimleri Fakültesi Sivas, Turkey

\section{Dilek ERYÜRÜK}

Zübeyde KORKMAZ

Öznur BAŞDAŞ

İlknur YILDIZ

Emine ERDEM

Meral BAYAT

The study was presented as a Poster Presentation at the 22-25 May 2013 National Pediatric Nursing Congress (Adiyaman).

Correspondence: Dilek Eryürük Erciyes Üniversitesi, Sağık Bilimleri Enstitüsü, Çocuk Sağlığı ve Hastalıkları Hemşireliği Doktora Programı Mezunu, Kayseri, Turkey

Phone: +905522417130

E-mail: deryuruk@hotmail.com

Received: 10 May 2021

Accepted: 30 January 2022

\begin{abstract}
Objectives: There has been an increasing demand for nurses with advanced professional qualifications. A professional self-concept and critical thinking in nurses are necessary for determining complicated patient care needs and for finding and applying accurate and practical solutions in patient management. This study conducted to determine level of critical thinking and professional self-concept and the relationship between these concepts in pediatric nurses.
\end{abstract}

Study Design: The study was conducted with 120 nurses working at a public hospital in Middle Anatolia in Turkey. The data were collected using a questionnaire, the Professional Self-Concept Scale in Nurses (PSCSN) and the California Critical Thinking Disposition Inventory (CCTDI).

Results: A significant positive association was found between the mean PSCSN and CCTDI scores of the nurses $(p<0.05)$. Educational and employment status, voluntary choice of job and communication with other health care professionals influenced the mean scores of professional self-concept and critical thinking in nurses.

Conclusion: It was determined that critical thinking ability is important in developing professional self-concept, and educational status, working position, choosing the profession willingly and communication with the other healthcare staff were effective on professional self-concept and critical thinking.

Keywords: Critical thinking, Pediatric nurses, Professional self-concept

\section{Pediatri Hemşirelerinde Profesyonel Benlik Kavramı ve Eleştirel Düşünme}

ÖZET

Amaç: Son yıllarda profesyonel nitelikleri gelişmiş hemşirelere duyulan gereksinim giderek artmaktadır. Hemşirelerin karmaşık hasta bakım gereksinimlerini saptayabilmeleri, en doğru ve pratik çözümü bulup hızla uygulamaları ve profesyonel bakım sunabilmeleri için profesyonel benlik kavramı ve eleştirel düşünmeleri gerekmektedir. Bu çalışma, çocuk hemşirelerinde eleştirel düşünme düzeyi ile mesleki benlik kavramı ve bu kavramlar arasındaki ilişkiyi belirlemek amacıyla yapılmıştır.

Çalışma Planı: Çalışma Türkiye'de Orta Anadolu'da bir devlet hastanesinde çalışan 120 hemşire ile gerçekleştirildi. Veriler Tanıtıı Bilgi Formu, Hemşirelerde Profesyonel Benlik Kavramı Ölçeği (HPBKÖ) ve California Eleştirel Düşünme Eğilimi Envanteri (CEDEE) kullanılarak toplandı.

Bulgular: Hemşirelerde Profesyonel Benlik Kavramı Ölçeği (HPBKÖ) ile California Eleştirel Düşünme Eğilimi Envanteri (CEDEE) puan ortalamaları arasında pozitif yönde anlamlı bir ilişki bulunmuştur $(p<0.05)$. Hemşirelerde eğitim ve istihdam durumu, mesleği isteyerek seçme ve diğer sağlık profesyonelleriyle iletişim, mesleki benlik kavramı ve eleştirel düşünme ortalamalarını etkilediği tespit edilmiştir.

Sonuç: Mesleki benlik kavramının geliştirilmesinde eleştirel düşünme yeteneğinin önemli olduğu, mesleki benlik kavramı ve eleştirel düşünme üzerinde eğitim durumu, çalışma pozisyonu, mesleği isteyerek seçme ve diğer sağlık personeli ile iletişimin etkili olduğu belirlenmiştir.

Anahtar Sözcükler: Eleştirel düşünme, Pediatri hemşireleri, Profesyonel benlik kavramı 
$\mathbf{T}$ here have been increasing demands and expectations for nurses with advanced professional qualifications who have high motivation and who are receptive to changes within the healthcare system because of more complicated and various patient groups, more complex and new treatment methods and recent rapid developments in science and technology (1). These scientific and technological advances lead to nurses living a proceeding of adaptation from a traditional model to professionalism and increase the importance and expectations of nurses to provide quality nursing care $(1,2)$. Despite these increased requirements and expectations for nurses, there are reported to be problems regarding the professional qualifications of nurses due to recent concerns about the social image of the nursing profession and the problems caused by the lack of nurses $(3,4)$.

A professional attitude or "professionalism" is a frame used by professionals in defining their works as a community role; thus, professionals emphasize value commitments based primarily on the "professional status" of their work (5). Nursing, which is currently becoming a recognized profession, aims at protecting and promoting the health of individuals and the community at large, thus preventing diseases and increasing the coping capacity of individuals and social groups using care and rehabilitative services (6). Professional identification means to be the nurses' perception of the profession and their adoption of moving in the role of a nurse. A nurse's Professional identity represents the nursing philosophy and the values and notions that guides the attitudes and allinteractions of the nurse $(5,6)$. Nurses should improve their thinking and analytical powers to find solutions to contemporary problems, to determine the needs for complicated patient care, to quickly apply the most accurate and practical solutions and to provide professional care $(6,7)$. Especially special field nurses such as pediatric nursing need to easily adapt to innovations and developments, search for knowledge, ask questions, think critically, find solutions to problems and have social awareness by maintaining intellectual development $(6,8)$. Because pediatric nurses should have well-developed critical thinking skills and a professional self-concept to communicate and interact with children and to coordinate care according to the age and period characteristics of the children. Critical thinking and professional self-concept have gained enhanced importance. For the reasons explained above, this study was conducted to examine both professional self-concept and critical thinking, which are very important in the development of professional awareness and professional identity in pediatric nursing.

\section{MATERIALS and METHODS}

This descriptive study carried out for defining level of critical thinking and professional self-concept and the relationship between these concepts in pediatric nurses.

This study was conducted in pediatric clinics of a public hospital. At the time of this study, 150 nurses worked in pediatric clinics of a public hospital, 120 of these nurses participated in the study. We explained the aim of this study to the pediatric nurses participating in this study. The questionnaires and return envelopes were delivered directly to pediatric nurses. Survey and question forms in the return envelopes were given directly to pediatric nurses (return rate $80 \%$ ). After the forms were filled, they were handed over to the research team in sealed envelopes.

The data were collected by question form that included the socio-demographic characteristics of the participants, the Professional Self-Concept Scale in Nurses (PSCSN) and the California Critical Thinking Disposition Inventory (CCTDI).

\section{The Professional Self-Concept Scale (PSCSN)}

The Professional Self-Concept Scale (PSCSN) in Nurses is a 36-item scale with 3 subscales (occupational satisfaction, professional competence, and professional attitude and skills) using a 4-point likert-type scale. The PSCSN was created for measuring the level of professional self-concept and validity; the reliability research was conducted by Sabancıoğulları, Doğan, and Bircan. The Cronbach's alpha was 0.87 , and the test/re-test reliability was 0.76 . The scale has 8 negative and 28 positive statements; the positive statements are scored ranging from "1=totally disagree" to "4=completely agree," whereas the negative statements are scored inversely. A higher score shows that nurses have positively improved their professional self-concept (9).

\section{The California Critical Thinking Disposition Inventory (CCTDS)}

The California Critical Thinking Disposition Inventory (CCTDS) was created for measuring the level of critical thinking by Facione in 1990 (10). The scale consists of 75 questions prepared as a 6-point Likert-type scale ranging from " $6=$ totally agree" to " $1=$ totally disagree". A score of over 50 for each factor indicates advanced critical thinking, while a score below 40 indicates poor critical thinking. The scale consists of 6 sub-sizes (truth-seeking, open-mindedness, analyticity, systematicity, self-confidence and inquisitiveness). While 280 and below from the scale total point 
shows the level of weak critical thinking, more than 350 points indicate the advanced critical thinking level. The Cronbach's alpha for the CCTDS was 0.92. The Cronbach's alpha of each factor ranged from 0.71 to $0.80(11,12)$. The Turkish version of the scale consists of 6 factors and 51 items. The validity and reliability study of the scale was studied by Kökdemir in 2003. As a result of the analysis, it was determined that the Cronbach alpha value of the whole scale was 0.88 and the Cronbach alpha value of each factor was between 0.61 and 0.78 (11).

\section{Ethical consideration}

Before the initiation of this study, ethics committee (2013/55) and the institutional permission was obtained. In addition, the aim of this study was explained to the pediatric nurses participating in this study.

\section{Statistical Analysis}

IBM SPSS Statistics 22.0 (IBM Corp., Armonk, New York, USA) package program was used to assess the data of the study. Distribution characteristics of the databy Kolmogorov-Smirnov normality test. Mann-Whitney $\mathrm{U}$ test was used in the comparison of two independent groups. ANOVA or Kruskal-Wallis test was used for the comparison of two or more independent groups. In the correlation analysis, Spearman correlation analysis was applied depending on the distribution of data in correlation analysis. Significance was set at $p<0.05$ with a $95 \%$ confidence interval.

\section{RESULTS}

The mean age of the nurses was $35.73 \pm 6.80$ years. They had worked for $15.30 \pm 7.78$ years with $4.49 \pm 4.17$ years of experience in the profession and in pediatric clinics, respectively. Of the nurses, $49.2 \%$ had bachelor's degrees and $95.0 \%$ had worked on rotation (Table 1 ).

The mean scores of the subscales of the PSCSN were $12.16 \pm 1.90$ (occupational satisfaction), $22.6 \pm 2.89$ (professional competence), and $74.06 \pm 6.69$ (professional attitude and skills); the mean total score of the overall scale was $108.84 \pm 8.80$ (Table 2). Age, gender, and work duration in the profession and in pediatric clinics were found not to affect the mean total score of the PSCSN ( $p>0.05$ ). Compared to other nurses, the mean total score of the PSCSN was higher $(p<0.05)$ for the nurses who had bachelor's degrees, who had higher degrees, who were in charge of the clinic, who had good communication with other healthcare staff, and who had willingly chosen this profession.
Table 1. Descriptive characteristics of the nurses $(n=120)$

\begin{tabular}{|c|c|}
\hline Characteristics & n (\%) \\
\hline \multicolumn{2}{|l|}{ Age (years) } \\
\hline $22-29$ & $20(16.7)$ \\
\hline $30-39$ & $64(53.3)$ \\
\hline $40-49$ & $34(28.3)$ \\
\hline $50-55$ & $2(1.7)$ \\
\hline \multicolumn{2}{|l|}{ Gender } \\
\hline Male & $4(3.3)$ \\
\hline Female & $116(96.7)$ \\
\hline \multicolumn{2}{|l|}{ Educational Status } \\
\hline Vocational Health School & $16(13.3)$ \\
\hline Associate degree & $41(34.2)$ \\
\hline Bachelor's degree & $59(49.2)$ \\
\hline Master of Science degree & $4(3.3)$ \\
\hline \multicolumn{2}{|l|}{ Working Duration (years) } \\
\hline $1-5$ & $17(14.2)$ \\
\hline $6-10$ & $17(14.2)$ \\
\hline $11-15$ & $22(18.3)$ \\
\hline $16-20$ & $26(21.7)$ \\
\hline $20-35$ & $38(31.7)$ \\
\hline \multicolumn{2}{|c|}{ Working Duration in Pediatric Clinic (years) } \\
\hline $0-5$ & $68(56.6)$ \\
\hline $6-10$ & $39(32.5)$ \\
\hline $11-15$ & $11(9.2)$ \\
\hline $16+$ & $2(1.7)$ \\
\hline \multicolumn{2}{|c|}{ Working Position of the Nurse } \\
\hline Clinic Charge Nurse & $7(5.8)$ \\
\hline Shift Nurse & $107(89.2)$ \\
\hline Other & $6(5.0)$ \\
\hline
\end{tabular}

Table 2.The mean scores of sub-dimensions of the PSCSN of the nurses

\begin{tabular}{|c|c|c|}
\hline Sub-Dimensions & Mean \pm SD & Median (Min-Max) \\
\hline $\begin{array}{l}\text { Occupational } \\
\text { Satisfaction }\end{array}$ & $12.16 \pm 1.90$ & $12.00(8-17)$ \\
\hline $\begin{array}{l}\text { Professional } \\
\text { Competence }\end{array}$ & $22.6 \pm 2.89$ & $22.00(15-28)$ \\
\hline $\begin{array}{c}\text { Professional Attitude } \\
\text { and Skills }\end{array}$ & $74.06 \pm 6.69$ & 74.00 (62-99) \\
\hline Total Score & $108.84 \pm 8.80$ & $108.0(89-129)$ \\
\hline
\end{tabular}




\begin{tabular}{|c|c|c|}
\hline Sub-Dimensions & Mean \pm SD & Median (Min-Max) \\
\hline Analyticity & $47.92 \pm 5.26$ & $49.09(34-58)$ \\
\hline Open-mindedness & $39.69 \pm 5.3$ & $40.00(30-66)$ \\
\hline Inquisitiveness & $41.20 \pm 6.62$ & $41.25(23-64)$ \\
\hline Self-confidence & $40.23 \pm 10.25$ & $40.00(16-79)$ \\
\hline Truth-seeking & $37.51 \pm 7.94$ & $37.14(15-39)$ \\
\hline Systematicity & $42.25 \pm 6.32$ & $41.66(20-60)$ \\
\hline Total Score & $248.82 \pm 23.76$ & $248.25(143-271)$ \\
\hline
\end{tabular}

The mean scores of the subscales of the CCTDS were as follows: $47.92 \pm 5.26$ (analyticity), $39.69 \pm 5.33$ (openmindedness), $41.20 \pm 6.62$ (inquisitiveness), 40.23 \pm 10.25 (self-confidence), $37.51 \pm 7.94$ (truth-seeking), $42.25 \pm 6.32$ (systematicity). The mean total score of the overall scale was $248.82 \pm 23.76$ (Table 3). Age, gender and work duration of the nurses did not affect the mean total CCTDS score ( $p>0.05$ ); it was determined that as the duration of education increased, the total CCTDS score increased and the mean total CCTDS score of the nurses who were in charge of the clinic was higher $(p<0.05)$.

The mean score of all subscales and the total score of the PSCSN, except for occupational satisfaction, and the mean score of all subscales and the total score of the CCTDS, except for open-mindedness and truth-seeking, were found to be significantly and positively correlated $(p<0.05)$ (Table 4).

\section{DISCUSSION}

\section{Professional Self-Concept}

Professional self-concept, which is defined as identification with the profession, has an important place in nursing because of its professional status and provision of quality services to the community $(4-5,13-15)$. The mean score of the PSCSN of the pediatric nurses in the present study was $108.84 \pm 8.80$. Compared to this study, other studies (4, $14,16)$ have reported higher PSCSN scores for nurses. This result can be explained by the inclusion of only pediatric nurses in this study, unlike other studies. Various studies that have determined professionalism using different scales have demonstrated that nurses have a good level of self-image (17) and that the level of professional selfconcept is low among nurses (18).
Age, gender and work durations in the profession and in pediatric clinics did not affect the mean total score of the PSCSN in this study ( $p>0.05)$. However, some studies reporting on professionalism for nursing have noted that as age and work duration of the nurses increased, the score of professional self-concept increased (14,19-20). Differently, Öner et al. (17) have reported professional selfscores of 1 st grade nursing students are higher than 4th grade nursing students.

Education plays a significant role on the professionalization of nursing. School training contributes to creating positive perception and thoughts about the profession and represents a major factor in the positive improvement of a professional identity $(4,14,21)$. According to the study results the mean total scores of the PSCSN of pediatric nurses who were graduates with bachelor's degrees and higher degrees was found to be higher than those of other nurses. Similarly, several studies have shown that the educational status of nurses affected their professionalism and that nurses with a higher educational status had higher professional self-concept levels $(18,22)$.

The mean total PSCSN scores of nurses who were in charge of the clinic, who had good communication with health care professionals, and who had willingly chosen the profession was higher than those of other nurses $(p<0.05)$. The high PSSCN scores of the pediatric clinic responsible nurses can be associated with their taking responsibility for the management of the pediatric clinics where many critical decisions are made and the application is made. In addition, it has been stated that the clinical features studied affect the professional self-score $(19,20)$. Sabancıoğulları and Doğan (4) similarly found that nurses who had willingly chosen their profession, who did not think about leaving the profession, who were considered to be hopeful about the future of the nursing and who recommended the profession to others had significantly higher mean total PSCSN scores. This result shows the importance of consciously choosing the nursing profession and the clinics where they work, and loving the profession. Other studies reported a higher level of professionalism in nurses who love their job, who do not want to change their profession, who think that their communication with team members is good, who are members of the professional association and who are in charge (14,19-20). Consistent with these results, it may be concluded that choosing the profession willingly and consciously, maintaining definite roles and responsibilities in the pediatric clinics and communicating with team members contribute to increasing professional motivation and favorably affect professional self-concept. 
Table 4.The correlation between PSCSN and CCTDS of the nurses

\begin{tabular}{|c|c|c|c|c|c|c|c|c|c|c|c|}
\hline & 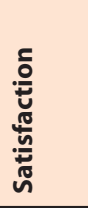 & 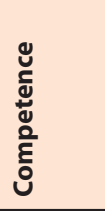 & 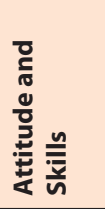 & 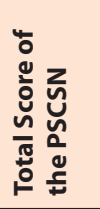 & 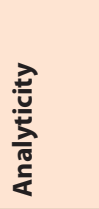 & 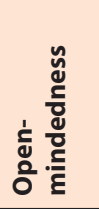 & 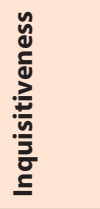 & 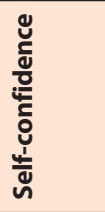 & 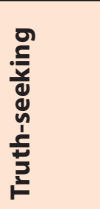 & 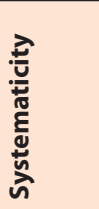 & 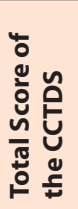 \\
\hline Satisfaction & $\begin{array}{l}1.000 \\
-\end{array}$ & & & & & & & & & & \\
\hline Competence & $\begin{array}{l}.018 \\
.849\end{array}$ & $\begin{array}{l}1.000 \\
- \\
\end{array}$ & & & & & & & & & \\
\hline Attitude and Skills & $\begin{array}{l}-.097 \\
.292\end{array}$ & $\begin{array}{l}.617^{* *} \\
.000\end{array}$ & $\begin{array}{l}1.000 \\
-\end{array}$ & & & & & & & & \\
\hline $\begin{array}{l}\text { Total Score of the } \\
\text { PSCSN }\end{array}$ & $\begin{array}{l}.136 \\
.139 \\
\end{array}$ & $\begin{array}{l}.762 * * \\
.000\end{array}$ & $\begin{array}{l}.939 * * \\
.000\end{array}$ & $\begin{array}{l}1.000 \\
- \\
\end{array}$ & & & & & & & \\
\hline Analyticity & $\begin{array}{l}073 \\
.426 \\
\end{array}$ & $\begin{array}{l}374 * * \\
.000\end{array}$ & $\begin{array}{l}437 * * \\
.000 \\
\end{array}$ & $\begin{array}{l}472 * * \\
.000 \\
\end{array}$ & $\begin{array}{l}1.000 \\
- \\
\end{array}$ & & & & & & \\
\hline Open-mindedness & $\begin{array}{l}.095 \\
300\end{array}$ & $\begin{array}{l}-.057 \\
537 \\
\end{array}$ & $\begin{array}{l}017 \\
.851 \\
\end{array}$ & $\begin{array}{l}016 \\
.861 \\
\end{array}$ & $\begin{array}{l}114 \\
.215 \\
\end{array}$ & $\begin{array}{l}1.000 \\
- \\
\end{array}$ & & & & & \\
\hline Inquisitiveness & $\begin{array}{l}026 \\
779 \\
\end{array}$ & $\begin{array}{l}481 * * \\
.000 \\
\end{array}$ & $\begin{array}{l}512 * * \\
.000 \\
\end{array}$ & $\begin{array}{l}542 * * \\
.000 \\
\end{array}$ & $\begin{array}{l}504 * * \\
.000 \\
\end{array}$ & $\begin{array}{l}-015 \\
.873 \\
\end{array}$ & $\begin{array}{l}1.000 \\
- \\
\end{array}$ & & & & \\
\hline Self-confidence & $\begin{array}{l}015 \\
874 \\
\end{array}$ & $\begin{array}{l}587^{* *} \\
.000 \\
\end{array}$ & $\begin{array}{l}415 * * \\
.000 \\
\end{array}$ & $\begin{array}{l}491 * * \\
.000 \\
\end{array}$ & $\begin{array}{l}413^{* *} \\
.000 \\
\end{array}$ & $\begin{array}{l}-177 \\
.053 \\
\end{array}$ & $\begin{array}{l}680 * * \\
.000 \\
\end{array}$ & $\begin{array}{l}1.000 \\
- \\
\end{array}$ & & & \\
\hline Truth-seeking & $\begin{array}{l}-009 \\
922\end{array}$ & $\begin{array}{l}-082 \\
.372 \\
\end{array}$ & $\begin{array}{l}-008 \\
.927 \\
\end{array}$ & $\begin{array}{l}-036 \\
.695 \\
\end{array}$ & $\begin{array}{l}-106 \\
.250 \\
\end{array}$ & $\begin{array}{l}579 * * \\
.000 \\
\end{array}$ & $\begin{array}{l}-091 \\
.322 \\
\end{array}$ & $\begin{array}{l}-288 * * \\
.001\end{array}$ & $\begin{array}{l}1.000 \\
-\quad \\
\end{array}$ & & \\
\hline Systematicity & $\begin{array}{l}026 \\
779 \\
\end{array}$ & $\begin{array}{l}233^{*} \\
.010 \\
\end{array}$ & $\begin{array}{l}139 \\
.131 \\
\end{array}$ & $\begin{array}{l}179 \\
.050 \\
\end{array}$ & $\begin{array}{l}427 * * \\
.000 \\
\end{array}$ & $\begin{array}{l}216^{*} \\
.018 \\
\end{array}$ & $\begin{array}{l}434 * * \\
.000 \\
\end{array}$ & $\begin{array}{l}305^{* *} \\
.001 \\
\end{array}$ & $\begin{array}{l}181^{*} \\
.048\end{array}$ & $\begin{array}{l}1.000 \\
- \\
\end{array}$ & \\
\hline $\begin{array}{l}\text { Total Score of the } \\
\text { CCTDS }\end{array}$ & $\begin{array}{l}067 \\
464\end{array}$ & $\begin{array}{l}448 * * \\
.000\end{array}$ & $\begin{array}{l}431 * * \\
.000\end{array}$ & $\begin{array}{l}468^{* *} \\
.000\end{array}$ & $\begin{array}{l}622 * * \\
.000\end{array}$ & $\begin{array}{l}433 * * \\
.000\end{array}$ & $\begin{array}{l}695^{* *} \\
.000\end{array}$ & $\begin{array}{l}558^{* *} \\
.000\end{array}$ & $\begin{array}{l}374 * * \\
.000\end{array}$ & $\begin{array}{l}693 * * \\
.000\end{array}$ & $\begin{array}{l}1.000 \\
-\quad\end{array}$ \\
\hline
\end{tabular}

\section{Critical Thinking}

According to the study results the critical thinking level of nurses was determined to be mediocre (the mean total CCTDS score was $248.82 \pm 23.76$ ). In other studies, nurses exhibited different levels of critical thinking (12,22-23). When the result is evaluated in terms of pediatric nurses who are expected to have a high level of critical thinking, it is thought that it may be affected by the pediatric clinic management style which expects nurses to carry out routine work and the expectation of working with excessive workload. In addition, individual self-development capability, different educational status and acceptance and receptiveness toward the nursing profession may be effective on the level of critical thinking.

In this study, age and work duration were not found to influence the critical thinking scores of nurses ( $p>0.05$ ), whereas other studies have indicated that as age progresses and work duration increases, the critical thinking scores of the nurses also increase $(20,23)$. The reasons for this may be the increased workload of nurses in pediatric clinics, high patient/nurse ratio, administrative factors, failure to develop a different perspective, and focus on routine care instead of taking a critical perspective.

Education plays an important role in increasing the level of critical thinking. As an individual's educational status increases, the individuals' level of critical thinking also increases $(22,24)$. In the present study, nurses with bachelor's degrees and higher degrees had a significantly higher mean CCTDS scores $(p<0.05)$. Positive perceptions and thoughts about the profession are important factors for improving critical thinking. In this study, the mean total CCTDS score of the nurses who had willingly chosen their profession was significantly higher than those of other nurses $(p<0.05)$. Öztürk and Ulusoy (25) reported that the mean total CCTDS scores of undergraduate nursing students and nursing students with a master of science degree who had willingly chosen the profession were high. Nurses with good communication are reported to have a high level of critical thinking $(20,21)$. 
The results of the study showed that pediatric nurses who had good communication with health care professionals had a higher average SCST score than the others $(p<0.05)$. Critical thinking power was high in pediatric nurses who were able to establish healthy social relationships, which is one of the most important characteristics expected from pediatric nurses.

Pediatric clinic manager nurses who have to make fast and accurate decisions should have critical thinking skills. In the study results, it was noted that the critical thinkings scores of the manager nurses working in the clinic were significantly higher than the other nurses in the clinic $(p<0.05)$. Erkuş (24) determined that manager nurses working in harmony with the team had high mean total CCTDS scores. Characteristics, such as recognizing problems and developing solutions for individuals working as management staff, improved the nurses' levels of critical thinking (12). This result may be related to that the manager nurses in pediatric clinic encountered problems more often and had to make faster decisions.

The mean score of all subscales and the total score of the PSCSN, except for satisfaction, and the mean score of all subscales and the total score of the CCTDS, except for open-mindedness and truth-seeking, were found to be significantly and positively correlated $(p<0.05)$. Park et al. (21) stated that there was a positive relationship between professional self and critical thinking in their study, Barry et al. (26) defined a negative relationship in their work using different scales.

According to the results of the research, professional selfconcept and critical thinking affect each other positively in pediatric nurses. As in all professions that struggle to develop a professional identity, pediatric nurses need to develop their thinking, questioning, research and analysis skills. By this way, pediatric nurses who can think critically can develop their professional identities effectively and accurately.

The mean score of all subscales and the total score of the PSCSN, except for occupational satisfaction, and the mean score of all subscales and total score of the CCTDS, except for open-mindedness and truth-seeking, were found to be significantly and positively correlated $(p<0.05)$. Consequently, it was determined in this study that critical thinking in pediatric nurses ability is important for developing a professional self-concept and that educational and work status, voluntary choice of profession and communication with other health care professionals were effective in developing a professional self-concept and critical thinking skills. According to these results, educational programs for improving the professional selfconcept and the critical thinking of all nurses, especially for pediatric nurses should be established and expanded.

\section{Study limitations}

The study was conducted with nurses working in the pediatric clinics. Therefore, the sample was limited to the number of nurses in the pediatric clinic of the hospital.

\section{REFERENCES}

1. Parandeh A, Khaghanizade M, Mohammadi E. Factors influencing development of Professional values among nursing students and instructors: a systematic review. Glob J Health Sci 2015; 7(2): 284293. DOI:10.5539/gjhs.v7n2p284.

2. Çöplü M and Kartın PT. Professional self-concept and Professional values of senior students of the nursing department. Nursing Ethics. 2018; 1(11): 1387-1397. DOI:10.1177/0969733018761171.

3. Vliegher K, Milisen K, Wouters R, et al. The professional selfimage of registered home nurses in Flanders (Belgium): A crosssectional questionnaire survey. ANR 2011; 24: 29-36. DOI:10.1016/j. apnr.2009.02.001

4. Sabancıoğulları S and Doğan S. Bir Entegre Eğitim Programından Yeni Mezun Olan Hemşirelerin Meslek ve Okul Eğitimine İlişkin Düşünceleri ve Profesyonel Kimlik Düzeyleri (Thoughts about the profession and school education and levels of professional identity of the nurses newly graduated from an integrated education institution). JNFN, 2012a; 20(3): 184-192.

5. Fagermoen S. Professional identity: values embedded in meaningful nursing practice. JAN 1997; 25(3): 434-441. DOI: 10.1046/j.1365-2648.1997.1997025434.x

6. Kaya A and Kantek F. Yönetici hemşirelerin profesyonel değerler algısı ve etkileyen faktörler (Nurse managers' perception of Professional values and affecting factors). Journal of Health and Nursing Management 2016; 3(1): 18-25. DOI:10.5222/SHYD.2016.01.

7. Riegel F, Crossettil MGO, Siqueira DS. Contributions of Jean Watson's theory to holistic critical thinking of nurses. Rev Bras Enferm 2008; 71(4): 2072-2076. DOI:10.1590/0034-7167-2017-0065

8. Nesje K. Nursing students' prosocial motivation: does it predict professional commitment and involvement in the job? J Adv Nurs 2015; 71(1): 115-125. DOI:10.1111/jan.12456.

9. Sabancıoğulları S, Doğan S, Bircan H. Öğrenci Hemşirelerde Profesyonel Benlik Kavramı Ölçeği Geliştirilmesi, Geçerlilik ve Güvenirlilik Çalışması, (Professional Self-Concept Scale in Clinician Nurses; Development, Reliability, Validity). Turkey Clinics Journal of Nursing Sciences 2011; 3(I): 16-28.

10. Facione $N$, Facione $P$, Sanchez $C$. Critical thinking disposition as a measure of competent clinical judgment: The development of the California critical thinking disposition inventory. JNE 1994; 3(8): 345350. DOI:10.3928/0148-4834-19941001-05.

11. Kökdemir D. Decision making and problem solving in cases of uncertainty (Master's thesis, University of Ankara), 2013. file:///C:/ Users/user/AppData/Local/Temp/127649.pdf

12. Zori S, Nosek LJ, Musil CM. Critical thinking of nurse managers related to staff RNs' perceptions of the practice environment. JNS 2010; 42(3), 305-313. DOI:10.1111/j.1547-5069.2010.01354.x

13. Sabancıoğulları $S$ and Doğan $S$. Development of professional identity and nursing. JANHS 2012b; 15(4): 275-282. 
14. Sabancıoğulları S and Doğan S. Mesleki kimlikgeliştirme programının hemşirelerin mesleki kimliği, iş doyumu ve tükenmişlik düzeylerine etkisi: Pilot çalışma (Effects of the professional identity development programme on the professional identity, job satisfaction and burnout levels of nurses: A pilot study). IJNP 2014(b); 21(6): 847-857. DOI:10.1111/ijn.12330.

15. Ibrahim RAE, Shazly MM, Saad NF. Critical thinking dispositions and problem solving abilities among nursing students. EJHC 2020; 11 (1): 161-176. DOI:10.21608/ejhc.2020.74775

16. Sabancıoğulları S and Doğan S. Bir Üniversite Hastanesinde Çalışan Hemşirelerin Profesyonel Benlik Gelişim Düzeyleri ve Etkileyen Faktörler (Level of development of the professional self-concept and affecting factors in the nurses working in a university hospital). JANHS 2014a; 17(1): 15-22.

17. Öner $H$, Koruklu N, Küçükoğlu NC. Hemşirelik öğrencilerinin profesyonel benlik kavramını yordayan değişkenler: özgüven ve sosyal sorun çözme becerisi (Varıable spredıctıng the professıonal self-conception of nursing students: self-confidence and social problem solvıng skill). Medical Science 2019; 14(4): 194-204. DOI:10.12739/NWSA.2019.14.4.1B0082

18. Hisar $F$ and Karadağ A. Determining the professional behaviour of nurse executives. IJNP 2010; 16(4): 335-341. DOI: 10.1111/j.1440-172X.2010.01849.x.

19. Şen N. Professional self perception of nurses working in pediatric units (Master'sthesis, Universty of Marmara), 2014. http://dspace. marmara.edu.tr/handle/11424/37282.

20. Misuk S, Jungsoon P, Okkyoung $K$, et al. The influence of clinical nurses' professional self concept and interpersonal relations on nursing competence. KJHM 2017; 22(2): 28-43. DOI:1226-6299 (pISSN).

21. Park S, Yourim J, Jang E, et al. Critical thinking disposition, professional self-concept and clinical competence in nursing students. J Int Korean Med 2016; 20 (1): 27-36. DOI:1226-5241(pISSN).

22. Kavaklı Ö, Uzun Ş, Arslan F. Yoğun bakım hemşirelerinin profesyonel davranışlarının belirlenmesi, (Determining the professional behaviours of intensive care unit nurses). Gulhane Med J 2009; 51: 168-173.

23. Wangensteen S, Johansson IS, Bjorkstrom ME, et al. Critical thinking dispositions among newly graduated nurses. JAN 2010; 66 (10): 2170-2181. DOI:10.1111/j.1365-2648.2010.05282.x

24. Erkuş B. Level of critical thinking and problem solving skills of administrator nurses working at private hospitals (Master's thesis, University of Marmara), 2011. file:///C:/Users/user/AppData/Local/ Temp/282381.pdf

25. Öztürk $\mathrm{N}$ and Ulusoy $\mathrm{H}$. Lisans ve yüksek lisans hemşirelik öğrencilerinin eleştirel düşünme düzeyleri ve eleştirel düşünmeyi etkileyen faktörler, Maltepe Üniversitesi Hemşirelik Bilim ve Sanatı Dergisi 2008; 1(1): 16-25.

26. Barry A, Parvan K, Tabrizi FJ, et al. Critical thinking in nursing students and its relationship with professional self-concept and relevant factors. Res Dev Med Educ. 2020; 9(7): 1-6. 